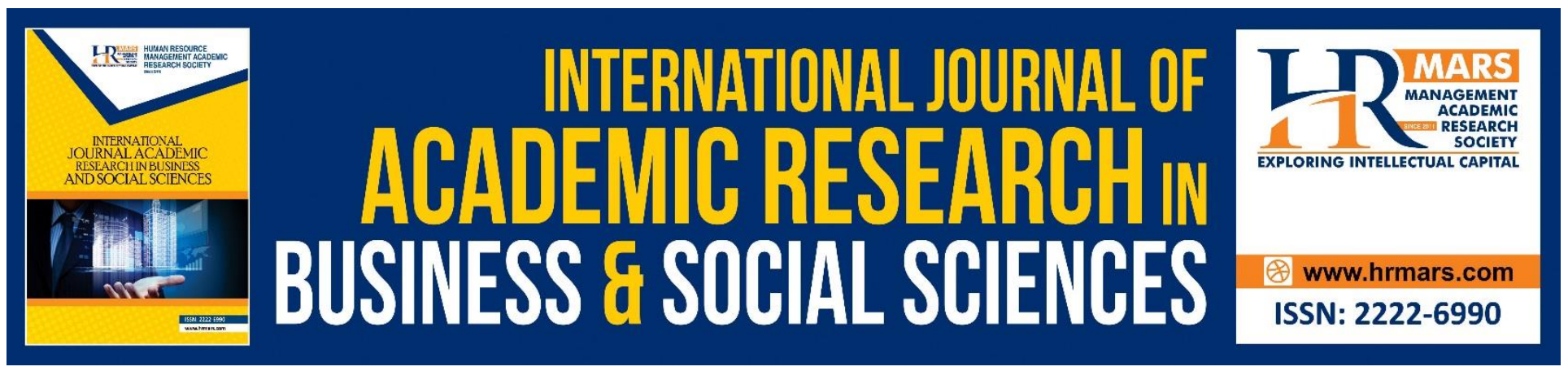

\title{
Volatility of Stock Return and Selected Macroeconomic Variables: Evidence from Nigeria Stock Exchange
}

\author{
Okonkwo, Jisike Jude
}

To Link this Article: http://dx.doi.org/10.6007/IJARBSS/v9-i6/5934

DOI: $10.6007 /$ IJARBSS/v9-i6/5934

Received: 09 April 2019, Revised: 11 May 2019, Accepted: 05 June 2019

Published Online: 23 June 2019

In-Text Citation: (Okonkwo \& Jude, 2019)

To Cite this Article: Okonkwo, \& Jude, J. (2019). Volatility Of Stock Return And Selected Macroeconomic Variables: Evidence From Nigeria Stock Exchange. International Journal of Academic Research In Business And Social Sciences, 9(6), 185-201.

Copyright: (C) 2019 The Author(s)

Published by Human Resource Management Academic Research Society (www.hrmars.com)

This article is published under the Creative Commons Attribution (CC BY 4.0) license. Anyone may reproduce, distribute, translate and create derivative works of this article (for both commercial and non-commercial purposes), subject to full attribution to the original publication and authors. The full terms of this license may be seen at: http://creativecommons.org/licences/by/4.0/legalcode

Vol. 9, No. 6, 2019, Pg. 185 - 201

Full Terms \& Conditions of access and use can be found at http://hrmars.com/index.php/pages/detail/publication-ethics 


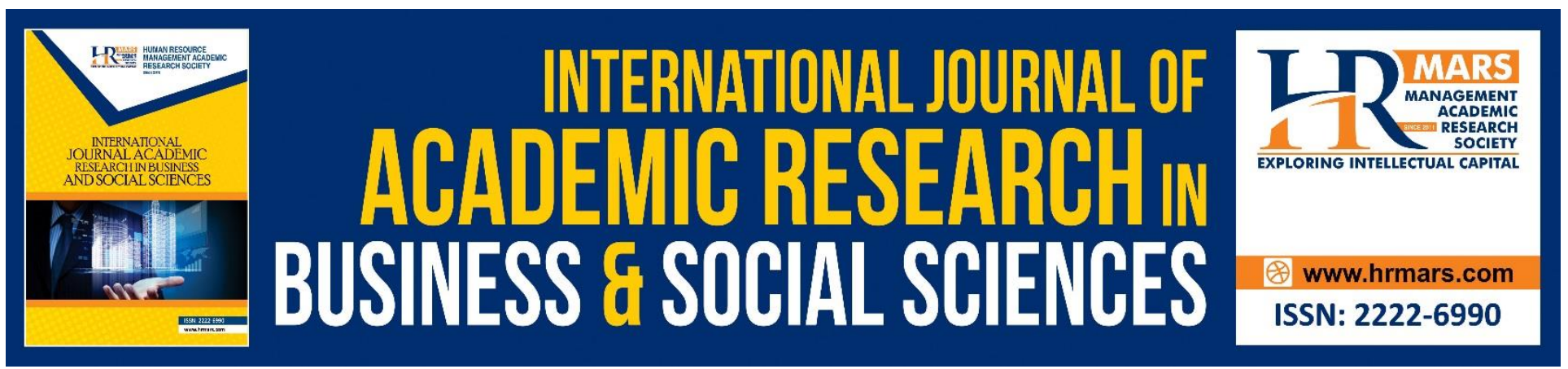

\title{
Volatility of Stock Return and Selected Macroeconomic Variables: Evidence from Nigeria Stock Exchange
}

\author{
Okonkwo, Jisike Jude, PhD \\ Department of Banking and Finance, Nnamdi Azikiwe University, Awka \\ Email: jj.okonkwo@unizik.edu.ng
}

\begin{abstract}
This study explored the casual nexus between stock return volatility and selected macroeconomic variables in an emerging stock market from 1981 to 2018. The study specifically reviewed the effect of industrial production and exchange rate on stock return volatility. The result of the Johansen Cointegration indicates the presence of a casual nexus between stock return volatility and selected macroeconomic variables in an emerging stock market in the long run. The granger causality impact assessment test revealed index of industrial production and exchange rate as the statistically significant macroeconomic variables that influence stock return volatility to a high extent. The result on the significant effect of industrial production and exchange rate lays credence to the existence of a positive and statistically significant relationship on stock return volatility. Investors are admonished to adjust their securities relative to changes in macroeconomic instability with regard to the index of industrial production which determines the level of industrial activities in an economy over a given period.
\end{abstract}

Keywords: Stock Return, Volatility, Macroeconomic variables, Nigerian Stock Exchange, Garch

\section{Introduction}

The performance of stock market is one of the enhancers to the development of an economy. A wellstructured stock market is essential for domestic and international capital mobility while an inefficient capital market limits economic development (Fernando, 2018). Thus, the volatility of the stock market can cause lots of financial risk such as affecting the cost of capital which tremendously hampers development of the economy. Demir (2019) suggests that any instability or crises occurring in these markets have partial or general effects on the economy. Volatility can greatly affect transactions of large magnitude instantaneously which may have long term implication for portfolio allocation, asset pricing and market risk measure. Osazevbaru (2014) stated that stock market volatility is a measure for variation of price of a financial asset over time which is concerned with the 
dispersion and not the direction of price changes. Some empirical studies like Khalid and Khan (2017) and Osazevbaru (2014) in their consensus views agree that stock market records guide investors in their decision-making process because not only are the investors interested in returns, but also in the uncertainty of such returns. Mutations in macroeconomic variables encourage volatility of stock returns as a result of instability in predictions. Haider, Haider and Ahmed (2017) opined that investors are interested to know about the factors affecting the working of stock to manage their portfolios while Oseni and Nwosa (2011) stated that in Nigeria, investors have a great interest in discovering variables that may help forecast stock prices. The growth of the macro economy cannot be achieved if fluctuation of stock market is not controlled. Stability in stock market prices restores public confidence and increases investors' participation. More participation by investors will increase market size and liquidity, as efficiency in the stock market work hand-in-hand with liquidity, which in return will help to reduce return volatility. Most investors believe that the growth and development of the economy is somehow uncertain and can be deduced from the direction of the value of their stocks. This can cause stock prices to be dependent on the investors' prediction about the dividend growth rate and thus induces higher return volatility.

Fernando (2018); Hasan and Zaman (2017); Jareno and Negrut (2016) agreed that stock market study that establishes empirical relationship between the stock returns and macroeconomic factors have proven to be much more challenging. The relationship between stock market return volatility and macroeconomic variables has engaged the attention of academics, stock market professionals and stock market regulators for so many years because of the strong link between the macro economy and the stock market (Baker, Bloom, Davis, and Kost 2019; Emenike and Okwuchukwu, 2014). A volatile stock market weakens consumer confidence and drives down consumer spending. It affects business investment because it conveys a rise in risk of equity investment (Mechri, Ben Hamad, Peretti, and Charfi 2019, Mala and Reddy, 2007). Such situation can change investment standard in an economy as investors divert to purchase stocks of larger well-known companies at the detriment of new companies. It can trigger a general rise in cost of capital and directly affect economic growth. Investors' portfolio allocation would be affected, as they would have to hold more stocks in their portfolios in order to reap the benefits of diversification (Frimpong and Oteng-Abayie, 2006). The problem of high instability of the financial sector has adversely affected the proper functioning of the market (Onakoya, 2013).

There have been a lot of theoretical studies on stock market volatility and macroeconomic variables. Demirer, Guota, Lv and Wong (2019) found that return dispersion conveys incremental information over stock market volatility beyond which is captured by business conditions. Osazevbaru (2014) and Elshareif, Tan and Wong (2012) in their consensus view believe that volatility does not have any measurable effect on long-term growth. Some other scholars Oseni and Nwosa (2011) discovered there is no causal relationship between stock market volatility and the volatility in macroeconomic variables. Empirical literatures on modeling and forecasting stock market volatility abound for developed stock markets and emerging stock markets of Asia and Europe. However, only a few studies have focused on the emerging markets of Africa. Examples of such few studies are Nyong (2003) for Nigeria and South Africa, Frimpong and Oteng-Abayie (2006) for Ghana, Eskandar (2005) for Egypt, Ogun, Beer and Nouyrigat (2005) for Kenya and Nigeria. These studies found evidence of volatility in the different markets studied. Specifically, for the Nigerian stock market, prior studies 
have either used only daily data or only monthly data. Also, the time varying variance property of the data has not been sufficiently addressed in the methodological approaches.

The objective of the study is to determine the effect of macroeconomic variables on stock return volatility: the effect of industrial production on stock return volatility; the effect of exchange rate on stock return volatility. Studies on stock return volatility and macroeconomic variables in Nigeria and other countries of the world have widely used money supply, interest rate, exchange rate, inflation and gross domestic as macroeconomic variables. This study improved on previous studies by including index of industrial production which reflects the level of industrial activities in the country in addition to lending rate, exchange rate, inflation and money supply. Furthermore, it used an upto-date data that is, from 1981 to 2018 to ensure large number of observation for reliability of result.

\section{Review of Related Literature}

The unconventional theory of Keynes (1936) suggests the significance of discovery process (forces of aggregate demand) in determining business cycle. This basis steered in the formulation of internal theories of business cycle which include the multiplier acceleration theory - Samuelson (1939). This theory showed that the interaction of the accelerator with the multiplier is capable under certain circumstances of generating continuous cyclical fluctuations. It posits that high output growth induces investment and high investment in-turn induces more output. This continues until there is a trough in the economy. At the point of a slump, the process works in the reverse order to stimulate recovery (Lucas, 1981 and Moore, 1983). Mele (2008) opined that stock market volatility is largely countercyclical, being larger in bad times than in good times. Accordingly, stock expected returns lower much less during expansions than they increase during recessions. The reason for this is because the investors' required return is not only countercyclical but also asymmetrically related to the development of the business cycle which happens when risk premia that is, the investors expected return to invest in the stock market increase more in bad times than they decrease in good time (Osazevbaru, 2014).

\section{Empirical Review}

Empirical studies reviewed showed that Osazevbaru (2014) studied measuring Nigerian stock market volatility using time series data of share prices for the period 1995 to 2009, the Autoregressive Conditional Heteroscedasticity (ARCH) model and Generalized Autoregressive Conditional Heteroscedasticity (GARCH) model were estimated. The findings showed that the market exhibits volatility clustering. It recommended that aggressive trading on a wide range of securities be encouraged as this will increase market depth and hence reduce volatility. Cunado, Gomez and Perez (2006) investigated financial liberalization and emerging stock market volatility using alternative methodologies of endogenous breakpoint detection that estimate the dates at which the behaviour of stock market volatility changed. The findings suggest that volatility has behaved in a different manner over the period. Olugbenga (2012) conducted a study and investigated the long-run and short-run effects of exchange rate on stock market development in Nigeria between 1985-2009 using the Johansen co-integration tests.

A bivariate model was specified and empirical results show a significant positive stock market performance to exchange rate in the short-run and a significant negative stock market performance 
INTERNATIONAL JOURNAL OF ACADEMIC RESEARCH IN BUSINESS AND SOCIAL SCIENCES Vol. 9, No. 6, June, 2019, E-ISSN: 2222-6990 @ 2019 HRMARS

to exchange rate in the long-run. The Granger causality test shows a strong evidence that the causation runs from exchange rate to stock market performance; implying that changes in the Nigerian stock market is explained by exchange rate fluctuation. Ndwiga and Peter (2016) examined volatility pattern of Kenyan stock market based on time series data which consists of daily closing prices of NSE Index from 2001 to 2014. The study used both symmetric and asymmetric Generalized Autoregressive Conditional Heteroscedastic (GARCH) models. The study provides evidence for the existence of a positive and significant risk premium. Moreover, volatility shocks on daily returns at the stock market are transitory.

There is no significant leverage effect. New regulations on foreign investors with a $25 \%$ minimum reserve of the issued share capital going to local investors (in 2002), introduction of live trading, cross listing in Uganda and Tanzania stock exchange (in 2006) and change in equity settlement cycle from $T+4$ to $T+3$ (in 2011) significantly reduce volatility clustering.

The onset of US tapering increase the daily mean returns significantly while reducing conditional volatility. Oseni and Nwosa (2011) investigated stock market volatility and macroeconomic variables volatility in Nigeria using $\operatorname{AR}(k)-\operatorname{EGARCH}(p, q)$ technique to examine the volatility in stock market and macroeconomic variables, and used LA-VAR Granger Causality test to analyze the nexus between stock market volatility and macroeconomic variables volatility in Nigeria for the periods 1986 to 2010 using time-series data. The results of the findings revealed that there exists a bi-causal relationship between stock market volatility and real GDP volatility; and there is no causal relationship between stock market volatility and the volatility in interest rate and inflation rate. The study recommended that in order to less the stock market volatile, government should take pro-active role in building a stable market through tapping the growing interest of general people in the market by increasing supply of shares. In a related study, Onakoya (2013) studied stock market volatility on economic growth in Nigeria for the periods of 1980 to 2010 using Exponential Generalized Autoregressive Conditional Heteroskedasticity (EGARCH). The findings showed that fluctuation shock is quite persistent in Nigeria and this might affect growth of the economy. The study recommended that for the stock market to be less volatile, the regulatory body should be strengthened both in terms of number, manpower and quality of the professionals involved with special focus on independent research, monitoring mechanism and prompt decision making.

Tah (2013) studied the relationship between market expected returns in two emerging markets. The GARCH-in-mean (GARCH-M) model was used for this study and the results show that the relationship between risk and return is quite different between the two stock markets. The findings indicate a negative and significant relationship between conditional mean and variance for Lusaka Stock Exchange whereas; there is no significant relationship between expected returns and conditional variance for Nairobi Stock Exchange. These results suggest that Nairobi Stock Exchange investors consider some other risk measure to be more important. Elshareif, Tan and Wong (2012) examined unexpected volatility shifts and efficiency of emerging stock market using Malaysia. The used the Iterated-Cumulative-Sum-of-Squares-in-Volatility model (ICSS-EGARCH-M Model), which is one of the new approaches in market efficiency studies. The findings indicated the rejection of Efficient Market Hypothesis for the market when sudden volatility shifts were considered.

The results also provided significant empirical evidences for positive risk-return relationship in the exchanges. The stock market was found to be more sensitive to global than local events. The 
asymmetrical responses to good and bad news were also part of the market behavior. Uyaebo, Atoi and Usman (2015) examined Nigeria stock market volatility in comparison with some Countries in application of asymmetric GARCH Models with endogenous break dummy on two innovation assumptions using daily all share index of Nigeria, Kenya, United States, Germany, South Africa and China spanning from February 14, 2000 to February 14, 2013. The best fitted models are compared in terms of conditional volatility reaction to market shocks and volatility persistence alongside the asymmetric properties. The findings reveal that volatility of Nigeria and Kenya stock returns react to market shock faster than as other countries do. The results also suggest the absence of leverage effect in Nigeria and Kenya stock returns, but confirm its existence in others. In conclusion, the paper suggested that less developed stock markets should improve on market infrastructure, quality of instrument traded on the floor and regulatory practices as such efforts could moderate its fast response to market fluctuations. Atoi (2014) tested volatility in Nigeria stock market using GARCH models. The study showed that the input of error distributions was neglected while modelling stock market volatility in Nigeria and studies have shown that the application of appropriate error distribution in volatility model enhances efficiency of the model. The study used the all Share Index between 2008 and 2013 to estimate first order symmetric and asymmetric volatility models each in Normal, Student's-t and generalized error distributions aiming to select the most suitable volatility model with the most correct error distribution. The findings of the study showed that the presence of leverage effect meaning that volatility responds more to bad news than it does to equal magnitude of good news. The news impact curves validate this result. The last twenty- eight days out-of-sample forecast adjudged Power-GARCH $(1,1)$ in student's t error distribution as the best predictive model based on Root Mean Square Error and Theil Inequality Coefficient. It recommended that empirical works should consider alternative error distributions with a view to achieving a robust volatility forecasting model that could guarantee sound policy decisions.

\section{Methodology}

The volatility in stock return in the presence of macroeconomic volatility was estimated using the GARCH models. The GARCH models are the most commonly employed class of time series models in the recent finance literature for studying volatility in stock return (Adeniji, 2015). To explore the casual nexus between stock return volatility and selected macroeconomic variables in an emerging stock market, this paper utilized the Johansen Co-integration methodology. Conversely, the effect of selected macroeconomic variables on stock return volatility was assessed suing the granger causality impact assessment test. The annual data relating to the subject of interest from 1981 to 2018 were sourced from the Central Bank of Nigeria statistical bulletin. In an attempt to ensure that the data were free from stationarity deficiencies in connection with most time series data, the unit root was performed. Furthermore, the model was subjected diagnostic test of test of serial correlation, Ramsey Specification, heteroskedasticity and test of multicollinearity.

\section{Variables Description}

Stock Return Volatility (SRV) is the dependent variable. Stock return volatility was proxied using the changes in the all share index of the Nigeria Stock Exchange. The use of percentage changes in the all share index is that it captures the actual change in market index of the stock exchange from the 
previous year to the current and, thus, if the stock listed on the exchange has grown it is positive and, if it has not, then it will be negative. Index of Industrial Production (IIP), Inflation (INF), Lending Rate (LDR), Exchange Rate (EXR) and Money Supply are the selected macroeconomic variables. These macroeconomic variables are capable of influencing emerging market stock returns. Increase in industrial activities in a country is expected to lower volatility in stock return in an emerging market. High fluctuation in inflation, lending rate, money supply and exchange rate depreciation would adversely increase the volatility in stock return.

\section{Model Specification}

The model of Adeniji (2015) was adopted with slight modification. Volatility in stock prices was expressed as a function of macroeconomic variables: gross domestic product, exchange rate, inflation, interest rate and money supply. The multivariate model of this study is advanced as: SRV = F (IIP, LDR, EXR, INT, MS) - . - . - . - - 3.1

Equ. 3.1 was transformed to log-linear econometric structure to obtain the coefficients of the elasticity of the variables, while reducing the possible impact that any outlier may have, hence interpretation becomes easy in elasticity terms. Thus:

$$
\begin{aligned}
& \operatorname{LogSRV}_{\mathrm{t}}=\mathrm{ao}+\mathrm{a}_{1} \log 11 \mathrm{P}_{\mathrm{t}}+\mathrm{a}_{2} \operatorname{LogLDRr}+\mathrm{a}_{3} \operatorname{LogEXR}_{\mathrm{r}}+\mathrm{a}_{4} \log _{\mathrm{L}} \mathrm{NF}_{\mathrm{t}} \\
& + \text { asLogMSt }+\varepsilon_{\mathrm{t}} \ldots \ldots \ldots
\end{aligned}
$$

Where: IIP, LDR, EXR, INT, and MS are index of industrial production, lending rate, exchange rate, inflation and money supply respectively in year $t$; ao is the coefficient constant; ao is the coefficient of independent variables; $\mathrm{SRV}_{\mathrm{t}}$ is stock return volatility in year $\mathrm{t}$; and $\varepsilon_{\mathrm{t}}$ is the error term in year $\mathrm{t}$

\section{Result of Data Analysis and Discussion Descriptive Statistics}

Table 4.1 depicts the descriptive statistics of the variables in the model. The skewness value for all the variable is in indication that the variables are positively skewed towards normality except for index of industrial production. The $p$-value of the Jarque-Bera shows that LDR, INF and MS are normally distributed while SRV, IIP and EXR are not normally distributed. 
INTERNATIONAL JOURNAL OF ACADEMIC RESEARCH IN BUSINESS AND SOCIAL SCIENCES Vol. 9, No. 6, June, 2019, E-ISSN: 2222-6990 @ 2019 HRMARS

Table 4.1 Descriptive Statistics

\begin{tabular}{|l|l|l|l|l|l|l|}
\hline & SRV & IIP & LDR & EXR & INF & MS \\
\hline Mean & 14585.33 & 131.7190 & 84.71839 & 81.47108 & 18.95839 & 4135789. \\
\hline Median & 7638.590 & 132.0000 & 17.9800 & 102.1052 & 11.80000 & 878460.0 \\
\hline Maximum & 50424.70 & 158.9000 & 2071.000 & 217.7900 & 72.80000 & 18579418 \\
\hline Minimum & 117.2800 & 100.0000 & 9.250000 & 0.893800 & 5.400000 & 22300.00 \\
\hline Std. Dev. & 15131.91 & 14.02713 & 368.6619 & 66.55185 & 17.77989 & 5873716. \\
\hline Skewness & 0.879409 & - & 5.29356 & 0.11016 & 1.69205 & 1.304282 \\
\hline Kurtosis & 2.736448 & 3.018501 & 29.02592 & 1.548396 & 4.71884 & 3.252237 \\
\hline Jarque-Bera & 4.085411 & 0.260950 & 1019.688 & 2.784451 & 18.60852 & 8.871458 \\
\hline Probability & 0.129677 & 0.877678 & 0.000000 & 0.248522 & 0.000091 & 0.011846 \\
\hline Sum & 452145.2 & 4083.290 & 2626.270 & 2525.603 & 587.7100 & $1.28 \mathrm{E}+08$ \\
\hline Sum Sq. Dev. & $6.87 \mathrm{E}+09$ & 5902.810 & 4022348 & 132874.5 & 9483.736 & $1.04 \mathrm{E}+15$ \\
\hline Observations & 31 & 31 & 31 & 31 & 31 & 31 \\
\hline
\end{tabular}

Source: Computer output data using E-views 8.0

\section{Diagnostic Test}

\section{Serial Correlation LM Test}

The serial correlation LM test is employed to determine if the variables in a model are serially correlated. Where the variables in the model are serially correlated, inferences drawn from the result would be incorrect and unreliable. The p-values (at $5 \%$ significance level) of the Breusch-Godfrey serial correlation test in Table $4.2 \mathrm{a}$ indicates that the variables in the models are free from autocorrelation, hence results from model estimation would be judged to be reliable. The serial correlation is preferred to Durbin Watson in testing autocorrelation in any proposed model.

Table 4.2a: Serial Correlation LM Test Result

\begin{tabular}{|l|l|l|l|}
\hline F-statistic & 5.440090 & Prob. F(2,23) & 0.0116 \\
\hline Obs*R-squared & 9.955247 & Prob.Chi-Square(2) & 0.0069 \\
\hline
\end{tabular}

Source: Computer output data using E-views

\section{Heteroskedasticity Test}

This is lagrange multiplier test of the null hypothesis of no heteroskedasticity in the residuals. Usually this vector contains the regressor from the original least square regression, but it is not necessary. The probability of the Chq. statistic in Table $4.2 \mathrm{~b}$ is significant at $5 \%$ level of significance, suggesting that there is no existence of heteroskedasticity in the model.

Table 4.2b: Heteroskedasticity Test Result

\begin{tabular}{|l|l|l|l|}
\hline F-statistic & 21.80627 & Prob. F(5,25) & 0.0000 \\
\hline Obs*R-squared & 25.21777 & Prob. Chi-Square(5) & 0.0001 \\
\hline Scaled explained SS & 25.92818 & Prob. Chi-Square(5) & 0.0001 \\
\hline
\end{tabular}


INTERNATIONAL JOURNAL OF ACADEMIC RESEARCH IN BUSINESS AND SOCIAL SCIENCES Vol. 9, No. 6, June, 2019, E-ISSN: 2222-6990 @ 2019 HRMARS

Source: Computer output data using E-views 8.0

\section{Ramsey RESET Specification}

The Ramsey RESET test examines whether the model is correctly specified/fitted or not. The rationale behind the test is that if non-linear combinations of the independent variables have any power in explaining the dependent variable, the model is not well specified. The $p$-value (at $5 \%$ significance level) in Table 4.2c entails that the model is well specified.

Table 4.2c: Ramsey RESET Specification Result

\begin{tabular}{|l|l|l|l|}
\hline & Value & df & Probability \\
\hline t-statistic & 2.593752 & 24 & 0.0159 \\
\hline F-statistic & 6.727459 & $(1,24)$ & 0.0159 \\
\hline Likelihood ratio & 7.660279 & 1 & 0.006 \\
\hline
\end{tabular}

Source: Computer output data using E-views 8.0

\section{Multi-collinearity Test}

Gujarati (2004) suggested a priori correlation analysis of the independent variables as way of detecting multi-collinearity in a model. The correlation matrix in Table $4.2 \mathrm{~d}$ for the variables indicates that all the variables are positively correlated with stock return volatility except inflation which has a negative correlation. The correlation between the independent variables in each of the model has a maximum of is 0.80 observed for EXR and MS. However, in view of that fact that exchange rate and money supply are external and financial sector (coming from two different sector of the economy) proxy respectively, the two variables were allowed to be in the model. Thus, the explanatory variables in the model are devoid of multi-collinearity defects.

Table 4.2d: Correlation Matrix

\begin{tabular}{|l|l|l|l|l|l|l|}
\hline & SRV & IIP & LDR & EXR & INF & MS \\
\hline SRV & 1.000000 & 0.170949 & 0.008938 & 0.805221 & 0.393577 & 0.747736 \\
\hline IIP & 0.170949 & 1.000000 & 0.206035 & 0.342487 & 0.070565 & 0.004587 \\
\hline LDR & 0.008938 & 0.206035 & 1.000000 & 0.131907 & 0.047161 & 0.071772 \\
\hline EXR & 0.805221 & 0.342487 & 0.131907 & 1.000000 & 0.438260 & 0.801463 \\
\hline INF & -0.393577 & 0.070565 & 0.047161 & 0.438260 & 1.000000 & 0.335639 \\
\hline MS & 0.747736 & 0.004587 & 0.071772 & 0.801463 & 0.335639 & 1.000000 \\
\hline
\end{tabular}

Source: Computer output data using E-vies 8.0

\section{Unit Root Test: Augmented Dickey-Fuller (ADF) Test}

At level and first difference, the ADF test was performed. The result in Table 4.3a gives inference that the variables are stationary, hence the variables are free from stationarity defect connected with most time series data. 
INTERNATIONAL JOURNAL OF ACADEMIC RESEARCH IN BUSINESS AND SOCIAL SCIENCES Vol. 9, No. 6, June, 2019, E-ISSN: 2222-6990 @ 2019 HRMARS

Table 4.3a: ADF Test Result

\begin{tabular}{|l|l|l|l|l|}
\hline \multicolumn{1}{|c|}{ Variables } & \multicolumn{1}{|c|}{$\begin{array}{c}\text { ADF Test } \\
\text { Statistic }\end{array}$} & $\begin{array}{c}\text { Test Critical } \\
\text { Value at 1\% }\end{array}$ & $\begin{array}{c}\text { Test Critical Valuye } \\
\text { at 5\% }\end{array}$ & $\begin{array}{c}\text { Order of } \\
\text { Integration/Remark }\end{array}$ \\
\hline SRV & $\begin{array}{l}-4.117427 \\
(0.00)\end{array}$ & -3.711457 & -2.981038 & $1(1) /$ Stationary \\
\hline IIP & -5.266548 & -3.646342 & -2.954021 & $1(1) /$ Stationary \\
\hline LDR & $\begin{array}{l}-5.805848 \\
(0.00)^{*}\end{array}$ & -3.639407 & -2.951125 & $1(0) /$ Stationary \\
\hline EXR & $\begin{array}{l}-4.618881 \\
(0.00)^{*}\end{array}$ & -3.646342 & -2.954021 & $1(1) /$ Stationary \\
\hline INF & $\begin{array}{l}-5.623109 \\
(0.00)^{*}\end{array}$ & -3.646342 & -2.954021 & $1(1) /$ Stationary \\
\hline MS & $\begin{array}{l}-10.31889 \\
(0.00)^{*}\end{array}$ & -2.639210 & -1.951687 & $1(1) /$ Stationary \\
\hline
\end{tabular}

Source: Computer Output using E-view 8.0.

\section{Phillips Perron(PP) Test}

The Phillips Perron Test was also conducted at level and first difference to evaluate the stationarity of the variables. In Table 4.3b, it was found that all the variables are stationary either at level form or first difference.

Table 4.3b: PP Test Result

\begin{tabular}{|l|l|l|l|l|}
\hline Variables & \multicolumn{1}{|c|}{$\begin{array}{c}\text { PP Test } \\
\text { Statistic }\end{array}$} & $\begin{array}{c}\text { Test } \\
\text { Critical Value at } \\
\mathbf{1 \%}\end{array}$ & $\begin{array}{c}\text { Test Critical Value } \\
\text { at 5\% }\end{array}$ & $\begin{array}{c}\text { Order of } \\
\text { Integration/Remark }\end{array}$ \\
\hline SRV & $\begin{array}{l}-5.396782 \\
(0.00)^{*}\end{array}$ & -3.679322 & -2.967767 & $1(1) /$ Stationary \\
\hline IIP & $\begin{array}{l}-5.245900 \\
(0.00)^{*}\end{array}$ & -3.646342 & -2.954021 & $1(1) /$ Stationary \\
\hline LDR & $\begin{array}{l}-5.806032 \\
(0.00)^{*}\end{array}$ & -3.639407 & -2.951125 & $1(1) /$ Stationary \\
\hline EXR & $\begin{array}{l}-4.612606 \\
(0.00)^{*}\end{array}$ & -3.646342 & -2.954021 & $1(1) /$ Stationary \\
\hline INF & -9.269562 & -3646342 & -2.954021 & $1(1) /$ Stationary \\
\hline MS & -10.73198 & -2.639210 & -1.951687 & $1(1) /$ Stationary \\
\hline
\end{tabular}

Source: Computer Output using E-view 8.0.

Note: In determining the truncation lag for PP test, the spectral estimation method selected is Bartlett Kernel and Newey-West method for Bandwidth, p-values are in parentheses where $\left({ }^{*}\right)$ and $\left({ }^{* *}\right)$ denotes significance at $1 \%$ and $5 \%$ respectively. 
INTERNATIONAL JOURNAL OF ACADEMIC RESEARCH IN BUSINESS AND SOCIAL SCIENCES Vol. 9, No. 6, June, 2019, E-ISSN: 2222-6990 @ 2019 HRMARS

\section{Ordinary Least Square Regression - SRV and Macroeconomic Variables}

The regression result in Table 4.4 shows that there is a positive relationship between exchange rate, money supply and stock return volatility while a negative relationship exists between index of industrial production, lending rate, inflation and stock return volatility. The relationship between stock return volatility and exchange rate is statistically significant at $5 \%$ level of significance. The coefficient of the constant 5879.863 is a suggestion that if index of industrial production, exchange rate, money supply, lending rate and inflation are held constant, the all share index which reflects stock return volatility would be 5879.86 points. The index of industrial production coefficient of 30.97612 is an indication that a percentage increase in index of industrial production would result to 30.97612 decrease volatility in stock return. This is in line with a priori expectation that the higher the level of industrial activities in a country, the lower the volatility in stock return. It would be deduced from lending rate and inflation coefficient of -2.059282 and -43.85122 that a percentage increase in lending rate and inflation would result to -2.059282 and -43.85122 points reduction in stock return volatility. This is not expected as during high inflationary period coupled with high lending rate, industrial production would be reduced, hence fluctuation associated with common stock return would be high. The money supply coefficient of 0.000621 signifies that a percentage increase volatility in stock return by 0.000621 points. For exchange rate, it is observed that exchange rate depreciation increases volatility in stock return in Nigeria by a margin of 137.74 points. From Table 4.4, exchange rate is the only macroeconomic variable that is significantly related with volatility in stock return.

Table 4.4 OLS Result for Stock Return Volatility and Macroeconomic Variables

Dependent Variable: Stock Return Volatility

\begin{tabular}{|c|l|l|l|l|}
\hline \multicolumn{1}{|c|}{ Variables } & \multicolumn{1}{c|}{ Coefficient } & \multicolumn{1}{|c|}{ Std. Error } & \multicolumn{1}{c|}{ t-Statistic } & \multicolumn{1}{c|}{ Prob. } \\
\hline C & 5879.863 & 18532.34 & 0.317276 & 0.7537 \\
\hline IIP & -30.97612 & 150.1871 & -0.206250 & 0.8383 \\
\hline EDR & -2.059282 & 4.999247 & -0.421186 & 0.6772 \\
\hline INF & 137.7361 & 57.00240 & 2.416322 & 0.0233 \\
\hline MS & -43.85122 & 107.5176 & -0.407851 & 0.6869 \\
\hline R-squared & 0.000621 & 0.000579 & 1.072342 & 0.2938 \\
\hline Adjusted R- squared & 0.683062 & Mean dependent var & 14585.33 \\
\hline S.E. of regression & 0.619675 & S.D. dependent var & 15131.91 \\
\hline Sum squared resid & 9331.927 & Akaike info criterion & 21.29226 \\
\hline Log likelihood & $2.18 \mathrm{E}+09$ & Schwarz criterion & 21.56980 \\
\hline F-statistic & -324.0300 & \multicolumn{2}{|c|}{ Hannan-Quinn criter. } & 21.38273 \\
\hline Prob (F-statistic) & 10.77597 & \multicolumn{5}{|l}{ Durbin-Watson stat } & 1.016935 \\
\hline
\end{tabular}

Source: Computer output data using E-views 8.0.

The Adjusted R-squared reveals that 61.97 variations in stock return was as a result of the combined changes in index of industrial production, exchange rate, money supply, lending rate and inflation. The F-statistic of 10.77597 with a p-value of 0.000013 infer that the selected macroeconomic 
INTERNATIONAL JOURNAL OF ACADEMIC RESEARCH IN BUSINESS AND SOCIAL SCIENCES Vol. 9, No. 6, June, 2019, E-ISSN: 2222-6990 @ 2019 HRMARS

variables statistically and significantly explained the changes in stock return within the period covered by the study. The Durbin Watson value of 1.016935 (not close to the bench mark of 2.0) is an indication of autocorrelation. However, this defect was corrected with the aid of the serial correlation test as evidenced in $\mathrm{p}$-value of F-statistic in Table 4.2a.

\section{The Casual Nexus of Stock Return Volatility and Macroeconomic Variables}

The stationarity test as substantiated in Table 4.3a and 4.3b inferred that all the variables are not encumbered stationarity defects of most time series data. To this effect, the long run relationship between the variables of interest was tested using the Johansen Co-integration approach and the result presented in Table 4.5a and 4.5b.

Table 4.5a: Unrestricted Co-Integration Rank Test (Trace)

\begin{tabular}{|c|c|c|c|c|}
\hline $\begin{array}{c}\text { Hypothesized } \\
\text { number of CE(s) }\end{array}$ & Eigen Value & Trace Statistic & $\begin{array}{c}0.05 \text { Critical } \\
\text { Value }\end{array}$ & Prob. \\
\hline None ${ }^{*}$ & 0.923644 & 194.2511 & 95.75366 & 0.0000 \\
\hline At most $1^{*}$ & 0.858636 & 119.6528 & 69.81889 & 0.0000 \\
\hline At most $2^{*}$ & 0.641063 & 62.91680 & 47.85613 & 0.011 \\
\hline At most $3 *$ & 0.518552 & 33.20313 & 29.79707 & 0.0195 \\
\hline At most 4 & 0.315639 & 12.00538 & 15.49471 & 0.1567 \\
\hline At most 5 & 0.034114 & 1.006563 & 3.841466 & 0.3157 \\
\hline
\end{tabular}

Source: Computer analysis using E-views 8.0.

Trace test indicates 4 co-integrating eqn(s) at the 0.05 level; * denotes rejection of the hypothesis at the 0.05 level; **Mackinnon-Haug-Michelis (1999) p-values.

The long run result in Table 4.5a and 4.5b indicate the existence of a long run casual nexus between stock return volatility and selected macroeconomic variables in Nigeria. This is evidenced from the trace and max-eigenvalue test which each indicated the presence of four (4) co-integrating equations at $5 \%$ level significance.

Table 4.5b: Unrestricted Co-Integration Rank test (Maximum Eigenvalue)

\begin{tabular}{|c|l|l|l|l|}
\hline $\begin{array}{c}\text { Hypothesized } \\
\text { number of CE(s) }\end{array}$ & Eigen Value & Trace Statistic & $\begin{array}{c}\text { 0.05 Critical } \\
\text { Value }\end{array}$ & Prob. \\
\hline None $^{*}$ & 0.923644 & 74.59825 & 40.07757 & 0.0000 \\
\hline At most ${ }^{*}$ & 0.858636 & 56.73602 & 33.87687 & 0.0000 \\
\hline At most 2 & 0.641063 & 29.71368 & 27.58434 & 0.0262 \\
\hline At most 3 & 0.518552 & 21.19774 & 21.13162 & 0.0489 \\
\hline At most 4 & 0.315639 & 10.99882 & 14.26460 & 0.1543 \\
\hline At most 5 & 0.034114 & 1.006563 & 3.841466 & 0.3157 \\
\hline
\end{tabular}

Source: Computer analysis using E-views 8.0.

Trace test indicates 4 co-integrating eqn(s) at the 0.05 level; * denotes rejection of the hypothesis at the 0.05 level; **Mackinnon-Haug-Michelis (1999) p-values. 
INTERNATIONAL JOURNAL OF ACADEMIC RESEARCH IN BUSINESS AND SOCIAL SCIENCES Vol. 9, No. 6, June, 2019, E-ISSN: 2222-6990 @ 2019 HRMARS

\section{Granger Causality Effect Assessment Test}

To test the significant effect of each macroeconomic variable on the stock return volatility, the study applied the granger causality effect assessment test and the outcome summarized in Table 4.6 reveals that there is a unidirectional relationship between index of industrial production, exchange rate, money supply and stock return volatility within the period under review at $5 \%$ level of significance. Causality flows from index of industrial production and exchange rate to stock return volatility in one hand, and from stock return volatility to money supply on the other hand. Index of industrial production has a significant effect on stock return volatility. This suggests that when an industrial activity in an economy is high, the volatility in stock return would be low because investors earn returns from investment. Exchange rate depreciation significantly affects volatility in stock return. The depreciation in exchange rate increases the volatility of quoted stock in an emerging stock market. This significant effect of exchange rate on stock return volatility confirms the regression result in Table 4.4 on the significant positive relationship between exchange rate and volatility in stock return. For instance, the continuous depreciation of the Nigeria Naira against the US dollar has affected the liquidity and foreign participation in the stock market. The Chief Executive Officer of the Nigerian Stock Exchange, Mr Oscar Onyema noted that foreign investors in Nigeria Stock Exchange fell by $15 \%$ between January and February, 2016. The level of foreign participation by foreign investors dropped to $38.48 \%$ in February, 2016 compared to $51.57 \%$ in January, 2016. A finding that is worthy of notice is the significant effect of stock return volatility on money supply. It is widely held in literature that unexpected change in the money supply and stock return are inversely related. Fluctuation in money supply alters the equilibrium position of money, hence prices of assets in an investor's portfolio would be altered. High growth in money supply increases stock return volatility as the monetary authority would likely increase monetary policy rate in order to curtail the money in circulation. From Table 4.6, there is no evidence significant effect of money supply on stock return, rather it's the stock return volatility that significantly influence the volume of money in circulation in Nigeria.

Table 4.6: $\quad$ Granger Causality Result DDO, EDD, INF and FD

\begin{tabular}{|l|l|l|l|l|}
\hline & \multicolumn{1}{|c|}{ Obs } & \multicolumn{1}{|c|}{ F-Statistic } & \multicolumn{1}{|c|}{ Prob. } & \multicolumn{1}{|c|}{ Remarks } \\
\hline IIP does not Granger Cause SRV & 29 & $\begin{array}{l}4.28013 \\
0.61828\end{array}$ & $\begin{array}{l}0.0257 \\
0.5472\end{array}$ & Causality \\
SRV does not Granger Cause IIP & & No Causality \\
\hline LDR does not Granger Cause SRV & 29 & 0.57690 & 0.5692 & Causality \\
SRV does not Granger Cause LDR & & 0.02245 & 0.9778 & NoCausality \\
\hline EXR does not Granger Cause SRV & 29 & 6.08366 & 0.0073 & Causality \\
SRV does not Granger Cause EXR & & 1.09885 & 0.3494 & NoCausality \\
\hline INF does not Granger Cause SRV & 29 & 0.34855 & 0.7092 & Causality \\
SRV does not Granger Cause MS & & 1.48477 & 0.2466 & NoCausality \\
\hline MS does not Granger Cause SRV & 29 & 2.07000 & 0.1481 & Causality \\
SRV does not Granger Cause MS & & 18.30930 & 0.0000 & NoCausality \\
\hline
\end{tabular}

Source: Computer analysis using E-views 8.0. 
INTERNATIONAL JOURNAL OF ACADEMIC RESEARCH IN BUSINESS AND SOCIAL SCIENCES Vol. 9, No. 6, June, 2019, E-ISSN: 2222-6990 (C) 2019 HRMARS

\section{GARCH Stock Return Volatility Measurement}

The measurement of the volatility in stock return in presence of macroeconomic fluctuation was assessed using the Gaussian distribution of GARCH estimation model and the result presented in Table 4.7. The addition of RESID $(-1)^{\wedge} 2\left(a_{i}\right)$ and GARCH $(-1)\left(\left(\beta_{j}\right)\right.$ is 0.62 is a fairly high suggesting that volatility shocks are quite persistent. However, this is not statistically significant as the $p$-value of GARCH (-1) is insignificant at $5 \%$ level of significance. Thus, today's volatility in stock returns would not be attributed to information about stock return in the past. From insignificant p-value of GARCH, stock return volatility is not significantly affected by its own ARCH and GARCH dynamics of its own shocks.

Table 4.7: $\quad$ GARCH Result on Stock Return Volatility

\begin{tabular}{|c|c|c|c|c|}
\hline Variable & Coefficient & Std. Error & z-Statistic & Prob. \\
\hline \multicolumn{5}{|c|}{ Mean Equation } \\
\hline$C\left(\lambda_{0}\right)$ & 9430.045 & 2625.616 & 3.591555 & 0.0003 \\
\hline $\operatorname{SRV}\left(\lambda_{1}\right)$ & $8.46 \mathrm{E}-06$ & $2.24 \mathrm{E}-06$ & 3.771689 & 0.0002 \\
\hline \multicolumn{5}{|c|}{ Variance Equation } \\
\hline$C(w)(\omega)$ & 45649319 & 55515518 & 0.822280 & 0.4109 \\
\hline $\operatorname{RESID}(-1) \wedge 2\left(\alpha_{i}\right)$ & 0.698110 & 1.215746 & 0.574224 & 0.5658 \\
\hline GARCH (-1) ( $(\mathrm{j})$ & -0.074935 & 1.152003 & -0.065048 & 0.9481 \\
\hline IIP & -36.10005 & 169.0185 & -0.213586 & 0.8309 \\
\hline LDR & -1.145487 & 64.25963 & -0.017826 & 0.9858 \\
\hline EXR & 136.6774 & 68.27956 & 2.001732 & 0.0453 \\
\hline INF & -44.30819 & 199.9962 & -0.221545 & 0.8247 \\
\hline MS & 0.000397 & 0.000539 & 0.735508 & 0.4620 \\
\hline R-squared & 0.662206 & \multicolumn{2}{|c|}{ Mean dependent var } & 14585.33 \\
\hline Adjusted R-squared & 0.594647 & \multicolumn{2}{|c|}{ S.D. dependent var } & 15131.91 \\
\hline S.E. of regression & 9634.088 & \multicolumn{2}{|c|}{ Akaike info criterion } & 21.00758 \\
\hline Sum squared resid & $2.32 \mathrm{E}+09$ & \multicolumn{2}{|c|}{ Schwarz criterion } & 21.42389 \\
\hline Log likelihood & -316.6174 & \multicolumn{2}{|c|}{ Hannan-Quinn criter } & 21.14329 \\
\hline Durbin-Watson stat & 0.948147 & & & \\
\hline
\end{tabular}

Source: Computer analysis using E-views 8.0.

\section{Findings}

The $p$-values of index of industrial production, lending rate, inflation and money supply are insignificant thus, macroeconomic instability in index of industrial production, lending rate, inflation and money supply does not affect stock return in Nigeria within the period of the study. Nevertheless, the $p$-value of exchange rate is significant at $5 \%$ suggesting that instability in exchange rate can be transmitted to volatility in stock return. This refutes the finding of Adeniji (2015) that variation in exchange rate does not transmit to stock price volatility in Nigeria. The result of the Johansen Cointegration indicates the presence of a casual nexus between stock return volatility and selected 
macroeconomic variables in an emerging stock market in the long run. The granger causality impact assessment test revealed exchange rate and index of industrial production as the statistically significant macroeconomic variables that influence stock return volatility to a high extent. This lays credence to the existence of a positive and statistically significant relationship on stock return volatility.

\section{Conclusion and Recommendations}

This study has been able to decompose macro-economic variables into some constituents with the motive of outlining the effect of the components to the performance indices. The study adopted and modified a model that examined macro-economic variable effect on stock return volatility. The study came up with more literature on the subject matter, reviewed exiting literature and made analysis that other researchers will make use of in related study. This study concludes that stock return volatility in the presence of macroeconomic instability is related in the long run and that instability in exchange rate can be transmitted to volatility in stock return.

The researcher then recommends that the monetary authority should continually work towards the stabilization of the exchange rate of Naira against other currencies of the world as this significantly impact on stock return volatility. The appreciation of Naira against other currencies would greatly improve return of stock quoted on the exchange, which in turn leads to development of the stock market. Exchange rate depreciation would make export oriented companies quoted on the exchange to earn less from exports and this may discourage investment in such firms. The fluctuation in macroeconomic variables would to some degree affect securities held by investors thus, investors are admonished to adjust their securities relative to changes in macroeconomic instability with regard to the index of industrial production, which determines the level of industrial activities in an economy over a given period.

\section{References}

Adeniji, S. O. (2015). An Empirical investigation of the relationship between stock market prices volatility and macroeconomic variables' volatility in Nigeria. European Journal of Academic Essays, Vol. 2(11), 1 - 12.

Arestis, P., Luintel, A. D. \& Luintel, K. D. (2001). Financial structure and economic growth. Centre for Economic and Public Policy Working Paper No. 06/05

Atoi, N. V. (2014). Testing volatility in Nigeria stock market using GARCH Models. Central Bank of Nigeria Journal of Applied Statistics, Vol. 5(2), 65 - 79.

Baker, S. R., Bloom, N., Davis, S. J., \& Kost, K. (2019). Policy News and stock market volatility. Hoover Institution Economics Working Paper. 19105

Cunado, E. J., Gomez, B. J., \& Perez, G. F. (2006). Financial liberalization and emerging stock market volatility. Retrieved from www.tandfonline.com.

Demir, C. (2019). Macroeconomic determinants of stock market fluctuations: The case of bist-100. Journal of Economies, Vol. 7(8), 1-14.

Demirer, R., Guota, R., Lv, Z. \& Wong, W. K. (2019). Equity return dispersion and stock market volatility; Evidence from multivariate linear and nonlinear casuality tests. Journal of Sustainability, Vol.11(351), 1-15. 
INTERNATIONAL JOURNAL OF ACADEMIC RESEARCH IN BUSINESS AND SOCIAL SCIENCES Vol. 9, No. 6, June, 2019, E-ISSN: 2222-6990 @ 2019 HRMARS

Elshareif, E. E., Tan, H. B., \& Wong, M. F. (2012). Unexpected volatility shifts and efficiency of emerging stock market: The case of Malaysia, Business Management Dynamics, Vol.1(10), 58 66.

Emenike, K. O. \& Okwuchukwu, O. (2014). Stock market return volatility and macroeconomic variables in Nigeria. International Journal of Empirical Finance, Vol.2(2), 75 - 82.

Eskandar, T. (2005). Modeling and forecasting Egyptian stock market volatility before and after price limits. The Economic Research Forum Working Paper No. 0310.

Fernando, A. (2018). Macroeconomic Impact on Stock Market Returns and Volatility: Evidence from Sri Lanka. Business and Economic Journal, Vol.9(4), 1-15.

Frimpong, J. M., \& Oteng-Abayie, E. F. (2006). Modeling and forecasting volatility of returns on the Ghana stock exchange using GARCH Models. America Journal of Applied Sciences, Vol.3 (10), $2042-2048$.

Haider, S. K. A., Haider, S. H., \& Ahmed, I. (2017). Systematic risk factors and stock return volatility. Applied Studies in Agribusiness and Commerce Scientific Paper, 11(1-2), 61-70.

Hasan, A., \& Zaman, A. (2017). Volatility nexus between stock market and macro- economic variables in Bangladesh: An extended GARCH approach. Scientific Annals of Economics and Business, Vol.64(2), 233-243.

Hongyu, P., \& Zhichao, Z. (2006). Forecasting financial volatility: Evidence from Chinese stock market. Working Paper in Economics and Finance, No.06/02. University of Durham.

Jareno, F., \& Negrut, L. (2016). US stock market and macroeconomic factors. Journal of Applied Business Research, Vol.32(1), 325-340.

Khalid, W., \& Khan, S. (2017). Effects of macroeconomic variables on the stock market volatility; The Pakistan experience. International Journal of Econometrics and Financial Management, Vol.5(2), 42-59.

Lucas, E. R. (1981) Studies in Business -Cycle theory. Cambridge Mass: MIT Press.

Mala, R., \& Reddy, M. (2007). Measuring stock market volatility in an emerging economy. International Research Journal of Finance and Economics, Vol.8(I), 126-133.

Mechri, N, Ben Hamad, S., Peretti, C., \& Charfi, S (2019). The Impact of the Exchange Rate Volatilities on Stock Markets Dynamics: Evidence from Tunisia and Turkey. Hal Archives -Ouvertes. 01766742v2

Mele, A. (2008). “Understanding Stock Market Volatility: A Business Cycle Perspective" Working Paper London School of Economics.

Moore, H. G. (1983). Business Cycles, Inflation and Forecasting. Ballinger Cambridge $2^{\text {nd }}$ edition.

Ndwiga, D., \& Peter, W. M. (2016). Stock returns and volatility in an emerging equity market: Evidence from Kenya. European Scientific Journal, Vol.12(4), 56-68.

Nyong, M. O. (2003). Predictability and volatility of stock returns in three emerging markets: Nigeria, South Africa and Brazil. Nigeria Journal of Economics and Development Matters, Vol.2 (1), 12 29.

Nzotta, S. M. (2014). Money, banking and finance. Owerri: Osprey Publishers.

Ogun, G., Beer, F., \& Nouyrigat, G. (2005). Emerging equity market volatility: An empirical investigation of markets in Kenya and Nigeria". Journal of African Business, Vol.6 (1 \& 2),139154. 
INTERNATIONAL JOURNAL OF ACADEMIC RESEARCH IN BUSINESS AND SOCIAL SCIENCES

Vol. 9, No. 6, June, 2019, E-ISSN: 2222-6990 (C) 2019 HRMARS

Olugbenga, A. A. (2012). Exchange rate volatility and stock market behaviour: The Nigerian experience.European Journal of Business and Management, Vol.4(5), 20 - 29.

Onakoya, A. B. (2013). Stock market volatility and economic growth in Nigeria. International Review of Management and Business Research, Vol.2(1), 15 - 26.

Osazevbaru, H. O. (2014). Measuring Nigerian Stock Market Volatility. Singaporean Journal of Business Economics and Management Studies, Vol.2(8), 69 - 84.

Oseni, I. O., \& Nwosa, P. I. (2011). Stock Market volatility and macroeconomic variables volatility in Nigeria: An exponential GARCH approach European Journal of Business and Management, Vol.3(12), $43-53$.

Porteba, J. M. (2000). Stock market wealth and consumption. Journal of Economic Perspectives Vol.14(2), $99-118$.

Tah, A. K. (2013). Relationship between volatility and expected returns in two emerging markets. Business and Economics Journal, Vol.84, $1-8$.

Uyaebo, S. O., Atoi, V. N. \& Usman, F. (2015) Nigeria stock market volatility in comparison with some countries: Application of asymmetric GARCH models. CBN Journal of Applied Statistics Vol.6 (2), 133-160. 